\title{
Compliance with Corporate Governance Guidelines: A Comparative Study of High-performing Private Commercial Banks and State-owned Commercial Banks in Bangladesh
}

\author{
Rezwanul Huque Khan \\ Assistant Professor, Institute of Business Administration, University of Dhaka \\ Md. Ziaul Haque
}

$\mathrm{PhD}$ Fellow, School of Business, University of International Business and Economics (UIBE)

\begin{abstract}
In recent years, state-owned commercial banks (SCBS) in Bangladesh have shown relatively low financial performance than most of the private commercial banks (PCBs) in the country. While several issues may have contributed to such low performance by SCBs, this study aims to explore whether and how (if any) compliance with Corporate Governance issued from Bangladesh Securities and Exchange Commission (BSEC) varies between SCBs and high-performing private commercial banks (HPCBs), and whether this variation of compliance causes performance differences. Annual reports of five SCBs and five HPCBs in 2015 have been used and experts have been consulted for data collection. Partial compliance (PC) method has been adopted to find out the compliance with corporate governance guidelines by SCBs and HPCBs. From the BSEC notification, we set up 94 variables out of which 7 main variables are extracted using STATA. Then a cross tabulation and a descriptive statistics are conducted by using SPSS and STATA to explore the selected banks' compliance. The study shows that the compliance rate of corporate governance by SCBs is $35 \%$ to $97 \%$ while HPCBs' compliance rate is $90 \%$ to $98 \%$. Under PC approach, the Overall Compliance Index of SCBs is $80 \%$ while HPCBs has an index of 95\%. The study shows that SCBs' rate of corporate governance compliance is weaker than HPCBs in most criteria set by BSEC and not satisfactory which might have caused low financial performance by SCBs. The findings of the study has practical and policy related implications to improve the performance of SCBs in Bangladesh.
\end{abstract}

Keywords: Corporate Governance, Compliance, Commercial Bank, Financial Performance, Bangladesh

\section{INTRODUCTION}

To establish and aid a healthy environment in the banking sector, corporate governance has become a widely discussed and debated issue, and gained considerable prominence among the banking sector professionals over the last decade. It is simply the rule of the game for a bank to foster its cohesive relations with its shareholders, its lenders and other stakeholders in the business community and the society at large. Lenders and investors need to be assured that the basic principles of corporate governance are in place and will be followed, that a company's dealings with stakeholders are fair and transparent, that the board of directors is held accountable and that the company deals with their stakeholders responsibly.

Corporate governance is usually considered as a set of codes and guidelines to be followed by companies' (Fernando, 2006). John and Senbet (1998) refer Corporate Governance as a way of strategy and composition which again act as a check on managerial self-centered behavior. Moreover, 'Corporate Governance creates a structure to control the internal management that reduces agency problem' too (Hossain et al., 2009). In its broad definition, corporate governance refers to a set of rules or institutions or practices that curtails the agency cost and the variation between social and private returns on corporate actions (Monk and Minow, 1996; Ararat and Ugar, 2003). But the most cited definition is given by finance committee on corporate governance in Malaysia. The report on corporate governance (2002) states: "Corporate governance is the process and structure used to direct and manage the business and affairs of the company towards enhancing business prosperity and corporate accountability with the ultimate objective of realizing long term shareholder value, whilst taking account the interests of other stakeholders". 
The importance of corporate governance lies in its potential to contribute for higher business performance and prosperity, systematic management and to offer stability in the banking system.

Given its increased importance, many countries have developed their locally defined codes of conduct for effective corporate governance. In Bangladesh, BSEC took the initiative to develop a corporate governance code of conduct in 2006 and amended it in 2012 to provide a comprehensive guidance on corporate governance to the Board of Directors and management of the financial institutions. Due to its relatively recent introduction, monitoring of corporate governance in Bangladesh poses a challenge with regards to the assessment of corporate governance compliance and its impact on banking sector's performance (Haque, 2014; Mia and Haque, 2014). Companies that are enlisted in corporate governance index have statistically been seen to have higher return on assets, net profit margin, and return on equity than the ones that are not listed in index (Cengiz, 2016). She further claims that the companies which have higher corporate governance rate, have a statistically significant higher market book value, and return on equity compared to the ones with lower corporate governance rate. As such, corporate governance is critical for a company's integrity, efficiency, long term growth and profitability

The banking system of Bangladesh consists of SCBs, private commercial banks, foreign commercial banks, and specialized banks. Since the independence of the country, SCBs play an important role in the economic development of Bangladesh. In recent years, performance of these SCBs is deteriorating and is relatively weak compared to private commercial banks. The return on asset of SCBs is less than industry average. The Return on Asset (ROA) of SCBs has gradually dropped down to negative ($0.6 \%$ ) in 2012 due to a huge net loss. Though it is increased in 2013 and became positive but eventually turned into again negative $(-0.6 \%)$ and negative $(-0.4 \%)$ at the end of 2014 and 2015 respectively. Return on Equity (ROE) of SCBs sharply declined from $10.9 \%$ to $-13.5 \%$ in 2014 due to huge loss incurred by BASIC bank and further slipped down to - $1.5 \%$ in 2015. In 2012, also the Net Interest Income (NII) of SCBs decreased but the situation became alarming in the subsequent year (2013) due to higher interest expenses which grew faster than interest earnings. It was accelerated by a sharp fall of interest income of BDT 10.5 billion of a SCB, Sonali Bank Limited and deteriorated afterwards. The expenditure income (EI) ratio of the SCBs was 84.5 percent and these banks continued to have high level of Nonperforming loan (NPLs).

In some instances, this declining performance has been attributed to high administrative and operating expenses, poor appraisal, inadequate follow-up and supervision of the loans disbursed, nonmaintenance of the minimum required Capital Adequacy Ratio (CAR) and so ones (BB annual report, 2015-2016). On the other hand, in general, PCBs especially high-performer banks have excelled and achieved better financial performance in this period while few performed high. In general, their high performance is reflected through various assessment indicators of the financial performance (e.g., profitability ratio, market ratio, and value added metrics etc.) reported by the individual banks (see BB annual report, 2015-2016). In this backdrop, it is imperative to explore how compliant the HPCBs were with the BSEC notified corporate governance and to compare their compliance rate with that of SCBs to assess the effect of compliance (or noncompliance) with corporate governance to banks' performance in the country. This study addresses this issue by selecting five SCBs and five HPCBs of Bangladesh and provides insights for managers and policy makers.

\section{INITIAL CONCEPTUALIZATION AND BUILDING HYPOTHESIS}

The prime motive of corporate governance is to attain the organizational objectives by understanding the association among different variables which are decided by consensus considering policies and programs (Choudhury and Hoque, 2006). The growth of banking sector has been found to have negative implications due to volatility and corruption (Serwa 2010; Lin and Huang, 2012; Moshirian and $\mathrm{Wu}, 2012$; Park, 2012). Large scale corporate governance reporting might be a political reaction and a signal for more transparency in light of the financial crisis (Marsh and Pfleiderer, 2010). Interaction among management boards, supervisory boards and monitoring by supervisory boards must be improved. For the execution of the 'pay for performance' principle and reporting for corporate governance improvement is necessary (Markus et al., 2012). Consequently, every country adopts a unique set of corporate governance procedures that are based on factors such as the country's legal and financial system, corporate ownership structures, culture and economic circumstances (Lemo, 2004; Davies and Schlitzer, 2008). If any organization wants to get an attractive investment, corporate governance practices play significant role in this regard (Ekwueme and Paul 2016). It may be argued 
that compliance with corporate governance guidelines enable banks to boost customer confidence, as Mamun and Khan (2014) shows that confidence on bank management is one of the key factors of customers' satisfaction.

Extant literature has discussed corporate governance from different dimensions to highlight its importance to comply with. In a study, Kim et al. (2012) reviewed corporate governance when it comes to ownership structure of domestic owned banks and stated ownership structure has vital role as it is a key determinant of corporate governance. Johnson et al. (2000) found that the flaw of official institutions for corporate governance had an important impact for the devaluation and stock market decline in the Asian crisis and corporate governance can be crucial moderator to determine macroeconomic problems in crisis situation. Again, a study shows that good corporate governance promotes correlations of accountability among the core corporate members and this may improve corporate performance as it makes management responsible to the board and the board accountable to the shareholders (Rezaee et al., 2003). Filatotchev et al. (2003) affirmed that excessive management control and ignorance of the governance process could be reduced by increasing the influence of outside directors. Best practice code was published in the Cadbury report which included recommendations for companies to establish audit committees comprising independent non-executive directors (Power, 2002). Wang et al. (2008) and Agoraki et al. (2010) found that board independence did not have any significant effect on bank profitability.

Gospel and Pendleton (2005) recommended that corporate governance essentially deals with the association among capital, management and labor, and it is concerned with who manages the firm, whose interest is governed and the various ways how control is exercised. The viability of dispersed ownership can be connected through informal relations of trusts and importance of reputations. However ownership structure across different countries can be explained by different corporate governance practices (Franks et al., 2009). Berlin et al. (1991) and Wen and Shao (2012) investigated the illustrative power of corporate governance mechanisms on the wealth effect of firms' new product strategies. They found that board size, board independence, audit committee independence, CEO equity-based pay, analyst following and shareholder rights are all of significance in describing the variations in the wealth effect of new product introductions. The results disclosed that the firms having better corporate governance practice will receive higher stock market valuation when announced new product strategies than those of firms with poorer governance mechanisms.

Lawrence and Marcus (2009) identified that the governance provisions recently mandated by the U.S. stock exchanges are less closely linked to firm operating performance than are those not so mandated. Again, Kin and Baruch (2008) showed that managerial pay dispersion - effective corporate governance, especially high board independence, strengthens the positive association between firm performance and pay dispersion. In a study of the relation between corporate governance attributes and perceived information asymmetry it is found that board independence, size of the audit committee, officer and director ownership alleviate the negative effect share prices that offer equity (John and Afshad, 2008). They also found that firm-level governance scores are positively related to the firm's auditor choice. Good corporate governance embodies both enterprise performance and accountability (The Ministry of Finance, Singapore, 2012).

Chaudhury et al. (2011) examined the disclosure of different factors of corporate governance for certain specific company composing twelve financial institutions, six commercial banks and six developments banks. Rehman and Din (2013) investigated the issues which cause poor corporate governance including inadequate transparency, inefficient boards, insider malpractices, lack of disclose fusion of the post of the chairman and that of the managing director and non- separation of ownership from management. Hasan and Hossain (2012) showed the overall disclosure level is 67\% which is not a good score because this score does not provide a good signal to the stakeholder. Hasan et al. (2013) assessed the corporate governance and financial disclosure on the analysis of annual report of twenty Bangladeshi companies with four different industries, each containing five companies. A recent study by Rahman et al. (2014) gives a positive view to all stakeholders who are associated with the banks and their study was an extension of previous study which mainly deals with the Corporate Governance disclosure in banking sector.

The compliance of corporate governance by Islamic Shariah Based banks in Bangladesh (ISBBs) is satisfactory with a range between $83 \%$ and $98 \%$ (Haque, 2014). In case of Independent directors and 
audit committee requirement, compliance rate is low having $78 \%$ to $98 \%$ and $78 \%$ to $81 \%$ respectively. Haque and Mia (2014) found Corporate governance notification compliance (CGNC) of Conventional Bank having Islamic windows (CBHIWs) were more satisfactory than that of ISBBs. This research unveiled that the compliance regarding independent directors, board of directors, CEO, $\mathrm{CFO}$, Audit committee, external/statutory audit, duties of CEO \& CFO is more satisfactory in ISBBs compared to CBHIWs.

Sate owned commercial banks (SCB) and Development financial Institutions (DIF) have been found more vulnerable compared to private commercial banks in respect of three categories of CAMEL. NPL to total loan and EIR are too high and provision maintenance ratio, ROA, ROE, liquidity ratio is too low in DFIs and SBC and this scenario also reflects negatively in the performance of banking industry in Bangladesh (Islam et al., 2014). Chowdhury and Islam (2007) stated that deposit and loan advances of nationalized commercial banks (NCBs) are less sensitive to interest changes than those of Specialized Banks (SBs).

Mosharaf (2015) argued the inferior performance of sate owned commercial banks can best be explained by corporate governance theory on state ownership of firms and contestable markets perspectives of banking policy. A collective performance of the indicators for state commercial banks and private commercial banks showed that the performance of the state commercial banks has been weaker than private commercial banks. Serious mismanagement and malpractices have occurred in the banking sector especially in SCBs as well as in the capital market though there is supervision and monitoring by the regulatory bodies such as Bangladesh Bank and BSEC (Ahmed, 2015). We therefore presume that:

H1: The overall compliance index of SCBs is less than HPCBs in Bangladesh

The collapse of the state owned companies raised alarms regarding the lack of vigilant supervision by their boards of directors and audit committees in the financial reporting process and auditing functions (Rezaee et al., 2003). We therefore presume that:

H2: Incase of board of directors SCBs are showing less compliance than HPCBs

Leung and Horwitz (2009) showed that the private firms with a more concentrated management (executive board) ownership displayed better capital market performance during the 13-month period of the Crisis in Hong Kong. They also revealed that private firms with more equity ownership by nonexecutive directors where the positions of CEO and board chairperson were occupied by the same individual experienced a smaller stock price decline. As such we assert:

H3: HPCBs are more compliant than SCBs in respect of Chief financial officer and company secretary

And H4: SCBs are more compliant than the HPCBs in respect of Duties of Chief executive officer and chief financial officer (DCEFO)

In the USA, earnings restatements of publicly traded companies and financial statement fraud had happened due to absence of responsible corporate governance of high profile companies. In addition to this Enron, Global Crossing, World com in the USA, Parmalat in Italy and MacMed, Master bond and Leisurenet in South Africa have increased the ever increasing attention on corporate governance in general and audit committees in particular (Sa'eed, 2013). We therefore assume that:

H5: Incase of audit committee SCBs are more compliant than HPCBs.

Mahmud et al. (2010) investigated the effect of firm-level governance on the firm's choice of an external auditor. They checked the relationship between corporate governance and auditor choice and how they may affect the strength of legal environment. We therefore presume that:

H6: HPCBs are more compliant than the SCBs in respect of External/ Statutory Auditors (ESA)

Kimberly et al. (2011) found that the cumulative abnormal returns for acquirers are significantly negative upon announcement of acquisitions for the full sample and for the related and diversifying sub-samples. They also found that the role of corporate governance is positive in determining wealth creation for their sample of acquiring firms. We therefore propose that:

H7: Incase of Subsidiary Company SCBs are showing more consistent compliance than HPPBCs 
Listed companies in Dhaka Stock Exchange are reporting corporate governance in the annual reports and the level of disclosure also provides an optimistic picture of corporate governance practice, still there is a room for development of corporate governance practice in terms of its quality and transparency (Haque, 2016). We therefore presume that:

H8: HPCBs are more compliant than SCBs in respect of Reporting and Compliance of Corporate Governance (RCC)

\section{Methodology OF THE STUdY}

This study has been conducted based on triangulation of quantitative and qualitative approach. This section discusses data collection, compliance variables, measurement approaches etc.

\subsection{Data Collection}

The research is based on secondary data. Annual reports of selected SCBs' and HPCBs in 2015, BSEC notification and data from DSE library were collected and used for analysis. Besides, personal query from the concerned personnel are made for effectiveness of the study. Among six SCBs in Bangladesh five have been selected and PCBs were selected based on their financial performance in 2015. Rahman (2016) argues that a company's financial performance is normally judged by a series of ratios, but the most representative and widely used one is Return on Assets (ROA) which is supplemented by Return on Equity (ROE) and Net Interest Margin (NIM). In this study, we have used the profitability ratio, the market ratio, and value added metrics and net profit of PCBs in 2016 to select the five high-performing banks.

\subsection{Selection of Compliance Items}

Table 1 below shows 7 main variables (particulars) extracted through STATA from 94 variables (generated using SPSS) which are stated in BSEC corporate governance guideline (summary in Appendix: Table 8). The bold alphabets of each word (in Table 1) have been taken to represent as short compliance key form. The 94 variables ensure whether a company maintains BSEC issued corporate governance guidelines or not. Both qualitative and quantitative information are present in those 94 variables. For the quantitative information, annual reports were sufficient to conduct this study. But it was not enough for the qualitative information. In that case, banks disclosure points were considered from the annual reports and consulted with the experts. All 94 items were considered equally important. When a company discloses an item in annual report, point "1" is awarded, otherwise a " 0 ". Considering the cohesiveness among 94 variables, the seven main variables generated using another statistical tool STATA are- board of directors (BOD), Chief Financial Officer $\&$ Head of Internal Audit and Company Secretary (CHC), Audit Committee (AC), External/ Statutory Auditors not to engage in (ESA), Subsidiary Company (SC), Duties of Chief Executive officer and Chief Financial Officer (DCEFO) and Reporting \& Compliance of Corporate Governance (RCC). To ensure the rigor and more accuracy, these variables are first analyzed by STATA and then SPSS to find out the different aspect of compliance. To find out the result of compliance with the guidelines, a Partial Compliance (PC) Approach measurement is done using Microsoft Excel.

Table1. The summary of checklists that each bank complies (based on BSEC guidelines)

\begin{tabular}{|l|c|c|c|}
\hline Particulars & Compliance Key & $\begin{array}{c}\text { Total number of } \\
\text { Item }\end{array}$ & $\begin{array}{c}\text { Percentage of } \\
\text { total no. }\end{array}$ \\
\hline Board of Directors & BD & 45 & $47.8 \%$ \\
\hline $\begin{array}{l}\text { Chief Financial Officer(CFO), Head of Internal } \\
\text { Audit and Company Secretary }\end{array}$ & CHC & 2 & $2.12 \%$ \\
\hline Audit Committee & AC & 27 & $28.7 \%$ \\
\hline External/ Statutory Auditors & ESA & 9 & $9.57 \%$ \\
\hline Subsidiary Company & SC & 5 & $5.31 \%$ \\
\hline $\begin{array}{l}\text { Duties of Chief Executive officer(CEO) and Chief } \\
\text { Financial Officer(CFO) }\end{array}$ & DCEFO & 4 & $4.25 \%$ \\
\hline $\begin{array}{l}\text { Reporting and Compliance of Corporate } \\
\text { Governance }\end{array}$ & RCC & 2 & $2.12 \%$ \\
\hline Total Items & & 94 & $100 \%$ \\
\hline
\end{tabular}




\subsection{Measurement Approaches}

While two approaches (i.e., Dichotomous and Partial Compliance) to measure the compliance with corporate governance guidelines are widely used, this study adopts Partial Compliance (PC) approach. Hasan and Hossain (2012) stated that PC approach shows more accurate result than Dichotomous Approach. Moreover, in their recent studies, Haque (2014) and Haque and Mia (2014) found that result of PC approach was more accurate and pragmatic than Dichotomous approach. Hence, for a better accuracy, in this study we use PC approach (for details see Al-Shiab, 2003) to measure corporate governance compliance of the selected banks.

\section{RESUlTS AND DisCUSSION}

Table 2 below shows that highest OCI of SCBs is $97 \%$ in the BDBL and lowest OCI is 35\% in BBL. JBL, ABL and SBL are having better position with $95 \%, 89 \%$ and $84 \%$ respectively. The Overall Compliance Index of SCBs is $80 \%$. These banks are found less compliant with SC and AC items and the level is below 80\%; while their highest compliance is observed with CHC (90\%). Furthermore, DCEFO, BD, and ESA show more than $80 \%$ compliance that is $80 \%, 81 \%$ and $82 \%$ respectively. On the other hand Table 3 shows that highest OCI of HPCBs is $98 \%$ in IBBL and lowest OCI is $90 \%$ in BDBL. PBL, BBL and CBL are in medium position and their compliance rate are $96 \%, 96 \%$, and 94\% respectively. The Overall Compliance Index of HPCBs is $95 \%$. More compliance from CHC and RCC items and the level is $100 \%$ and medium compliance in DCEFO and BD those are $95 \%$ and $92 \%$ respectively whereas lowest number of notifications was complied in $\mathrm{AC}$ and that is $86 \%$. Furthermore, the second compliance items are SC and ESA and which is 96\%. It is also found that the Overall Compliance Index of SCBs is $80 \%$ and HPPBCs is $95 \%$ whereas different studies on compliance of corporate governance notification of Islamic Shariah based banks (ISBBs) in Bangladesh and conventional banks having Islamic windows (CBHIWs) in Bangladesh found overall compliance rate are 94\% and 95\% (Haque, 2014; Haque and Mia, 2014). Besides, all SCBs are not compliant with all guidelines of BSEC whereas compliance from CHC, ESA, DCEFO is $100 \%$ by ISBBs (Haque, 2014) and compliance from CHC and RCC items is $100 \%$ by CBHIWs (Haque and Mia, 2014).It is clear that SCBs corporate governance compliance is worse than not only from HPCBs but also from ISBBS and CBHIWs in Bangladesh. So our first hypothesis cannot be rejected that overall compliance of SCBs is less than HPCBs in Bangladesh.

Table2. Overall Compliance analysis of SCBs through PC approach

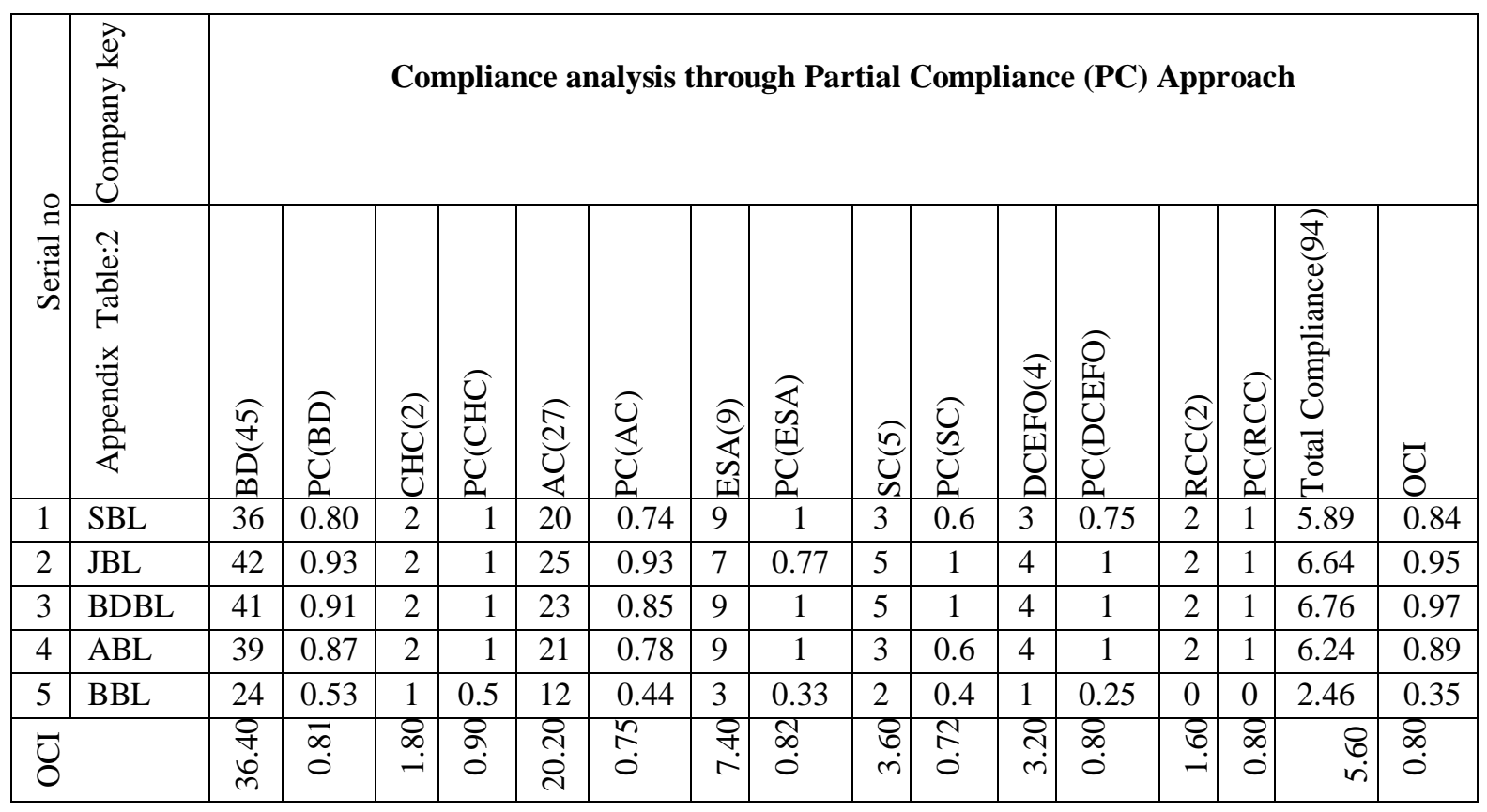


Compliance with Corporate Governance Guidelines: A Comparative Study of High-performing Private Commercial Banks and State-owned Commercial Banks in Bangladesh

Table3. Compliance analysis of HPCBs through PC Approach

\begin{tabular}{|c|c|c|c|c|c|c|c|c|c|c|c|c|c|c|c|c|c|}
\hline \multirow[b]{2}{*}{ 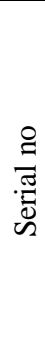 } & 志 & \multicolumn{16}{|c|}{ Compliance analysis through partial compliance (PC) Approach } \\
\hline & 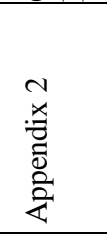 & 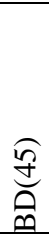 & $\widehat{\widehat{\vartheta}}$ & 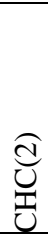 & 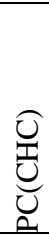 & 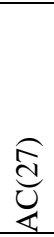 & 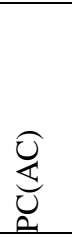 & 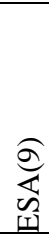 & 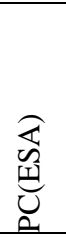 & $\underset{\widetilde{n}}{\overparen{n}}$ & 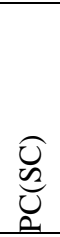 & 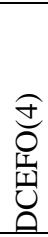 & 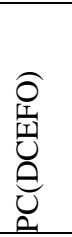 & 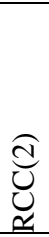 & 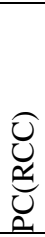 & 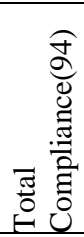 & $\bar{O}$ \\
\hline 1 & DBBL & $\overline{40}$ & 0.89 & 2 & 1 & 24 & 0.89 & 9 & 1 & 4 & 0.8 & 3 & 0.75 & 2 & 1 & 6.33 & 0.90 \\
\hline 2 & PBL & 43 & 0.96 & 2 & 1 & 23 & 0.85 & 8 & 0.89 & 5 & 1 & 4 & 1 & 2 & 1 & 6.70 & 0.96 \\
\hline 3 & BBL & 40 & 0.89 & 2 & 1 & 23 & 0.85 & 9 & 1 & 5 & 1 & 4 & 1 & 2 & 1 & 6.74 & 0.96 \\
\hline 4 & CBL & 41 & 0.91 & 2 & 1 & 21 & 0.78 & 8 & 0.89 & 5 & 1 & 4 & 1 & 2 & 1 & 6.58 & 0.94 \\
\hline 5 & IBBL & 43 & 0.96 & 2 & 1 & 25 & 0.93 & 9 & 1 & 5 & 1 & 4 & 1 & 2 & 1 & 6.88 & 0.98 \\
\hline & OCI & 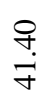 & ô & $\underset{8}{8}$ & $\stackrel{8}{8}$ & $\begin{array}{l}\text { กิ } \\
\text { กิ }\end{array}$ & $\begin{array}{l}0 \\
\infty \\
0\end{array}$ & $\begin{array}{l}8 \\
\infty \\
\infty\end{array}$ & $\stackrel{\circ}{\circ}$ & 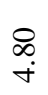 & $\stackrel{\circ}{\circ}$ & $\begin{array}{l}\infty \\
\dot{m}\end{array}$ & $\stackrel{n}{o}$ & $\underset{8}{8}$ & $\underset{8}{8}$ & $\begin{array}{l}\vec{t} \\
\text { 0. }\end{array}$ & $\stackrel{n}{o}$ \\
\hline
\end{tabular}

Table 4 below shows that SCBs and HPCBs in Bangladesh do not fully comply with all notifications issued by BSEC regarding the board of directors that includes forty five items. It shows that for board of director variables mean is 35.4 and standard deviation is 7.057 in SCBs whereas mean is 41.2 and standard deviation is 1.30 in HPCBs that means compliance rate regarding board of director notifications are less and more varied among SCBs than HPCBs in Bangladesh. So our second hypothesis is supported that incase of board of directors SCBs are showing less compliance than HPCBs.

Table4. Compliance of Notification regarding Board of Director

\begin{tabular}{|l|l|l|l|l|l|l|l|l|l|}
\hline \multicolumn{4}{|c|}{ tabstat BD, stat(mean sd min max) SCBs } & \multicolumn{3}{c|}{ tabstat BD, stat(mean sd min max) HPCBs } \\
\hline Variable & mean & sd & min & Max & Variable & mean & sd & $\min$ & $\max$ \\
\hline BD & 35.4 & 7.056912 & 24 & 42 & CHC & 41.2 & 1.30384 & 40 & 43 \\
\hline
\end{tabular}

We found from the cross tabulation result in Table 5 that all SCBs in Bangladesh do not fully comply with all notifications issued by BSEC regarding the chief financial officer, head of internal audit and company secretary requirement while HPCBs are fully compliant with this requirement for the improvement of corporate governance. So, our third hypothesis that HPCBs are complying more than the SCBs in respect of Chief financial officer and company secretary (CHC) cannot be rejected.

Table5. Compliance of Notification regarding $\mathrm{CHC}$

\begin{tabular}{|l|c|c|c|c|c|c|c|c|c|}
\hline \multicolumn{3}{|c|}{ tabstat CHC, stat(mean sd min max) SCBs } & \multicolumn{4}{c|}{ tabstat } & \multicolumn{3}{c|}{ CHC, stat(mean sd min max) HPCBs } \\
\hline Variable & Mean & Sd & $\min$ & $\max$ & Variable & mean & sd & $\min$ & $\max$ \\
\hline CHC & 1.8 & .4472136 & 1 & 2 & CHC & 2 & 0 & 2 & 2 \\
\hline
\end{tabular}

The following table shows that all SCBs and HPCBs in Bangladesh do not fully comply with all notifications issued by BSEC regarding the audit committee that includes twenty seven items. It shows that audit committee variable mean is 19.4 and standard deviation is 5.13 in SCBs whereas mean is 23 and standard deviation is 1.41 in HPCBs that means compliance rate regarding audit committee notifications are less and more varied among SCBs than HPCBs in Bangladesh. So our fifth hypothesis is rejected because audit committee of SCBs is showing less compliance than HPCBs.

Table6. Compliance of Notification regarding Audit Committee

\begin{tabular}{|l|l|l|l|l|l|l|l|l|l|}
\hline \multicolumn{4}{|c|}{ tabstat AC, stat(mean sd min max) SCBs } & \multicolumn{4}{c|}{ tabstat AC, stat(mean sd min max) HPCBs } \\
\hline Variable & mean & sd & min & max & Variable & mean & sd & $\min$ & $\max$ \\
\hline AC & 19.4 & 5.128353 & 12 & 25 & AC & 23 & 1.414214 & 21 & 25 \\
\hline
\end{tabular}

It is noticed from Table 7 that all SCBs and HPCBs in Bangladesh do not comply fully with all guidelines issued by BSEC regarding the external and statutory auditor that include nine compliance items. It shows that external/statutory auditor variable mean is 7.4 and standard deviation is 2.60 in SCBs where mean is 8.6 and standard deviation is 0.5478 in HPCBs. It means compliance with external/statutory auditor variable is less and more varied among SCBs than HPCBs in Bangladesh. So our sixth hypothesis is also accepted since HPCBs are complying more than the SCBs in respect of ESA. 
Rezwanul Huque Khan \& Md. Ziaul Haque

Table7. Compliance of Notification regarding External/Statutory Auditor

\begin{tabular}{|c|c|c|c|c|c|c|c|c|c|}
\hline \multicolumn{3}{|c|}{ tabstat ESA, stat(mean sd min max) SCBs } & \multicolumn{3}{c|}{ tabstat } & \multicolumn{3}{c|}{ ESA, stat(mean sd min max) HPCBs } \\
\hline Variable & mean & sd & $\min$ & $\max$ & Variable & mean & sd & $\min$ & $\max$ \\
\hline ESA & 7.4 & 2.607681 & 3 & 9 & ESA & 8.6 & .5477226 & 8 & 9 \\
\hline
\end{tabular}

Table8. Compliance of Notification regarding Subsidiary Company

\begin{tabular}{|c|l|l|l|l|l|l|l|l|l|}
\hline \multicolumn{4}{|c|}{ tabstat SC, stat(mean sd min max) SCBs } & \multicolumn{4}{c|}{ tabstat SC, stat(mean sd min max) HPCBs } \\
\hline Variable & mean & sd & min & Max & Variable & mean & sd & min & $\max$ \\
\hline SC & 3.8 & 1.30384 & 2 & 5 & SC & 4.8 & .4472136 & 4 & 5 \\
\hline
\end{tabular}

Again, Table 8 above illustrates that selected banks are not fully compliant with all BSEC guidelines regarding the subsidiary company which include five items for the improvement of corporate governance. It shows that SC variable mean is 3.8 and standard deviation is 1.30 for SCBs, in contrast to 4.8 and .447 of HPCBs that means compliance regarding subsidiary company notifications are more consistent in HPCBs comparing to SCBs. So our seventh hypothesis is not supported as subsidiary companies of SCBs are showing less consistent compliance than HPCBs.

Table9. Compliance of Notification regarding Duties of CEO and CFO

\begin{tabular}{|c|c|c|c|c|c|c|c|c|c|}
\hline tabstat & \multicolumn{3}{c|}{ DCEFO, stat(mean sd min max) SCBs } & \multicolumn{4}{|c|}{ tabstat } & \multicolumn{5}{c|}{ DCEFO, stat(mean sd min max) HPCBs } \\
\hline Variable & Mean & Sd & min & Max & Variable & mean & sd & min & $\max$ \\
\hline DCEFO & 3.2 & 1.30384 & 1 & 4 & DCEFO & 3.8 & .4472136 & 3 & 4 \\
\hline
\end{tabular}

It is observed from this table that all SCBs and HPPBCs in Bangladesh do not fully comply with notifications issued by BSEC regarding the duties of chief executive officer and chief financial officer that includes four compliance items for the improvement of corporate governance. But HPCBs shows more compliance than SCBs. So our fourth hypothesis is rejected for the reason that SCBs are complying less than the HPCBs in respect of DCEFO.

Table10. Compliance of Notification regarding Reporting and compliance of CG

\begin{tabular}{|l|l|l|l|l|l|l|l|l|l|}
\hline \multicolumn{2}{|c|}{ tabstat } & \multicolumn{3}{c|}{ RCC, stat(mean sd min max) SCBs } & \multicolumn{3}{c|}{ tabstat } & \multicolumn{3}{c|}{ RCC, stat(mean sd min max) HPCBs } \\
\hline Variable & mean & sd & min & max & Variable & mean & sd & min & max \\
\hline RCC & 1.6 & .8944272 & 0 & 2 & RCC & 2 & 0 & 2 & 2 \\
\hline
\end{tabular}

It is seen from this table (Table 10) that SCBs in Bangladesh do not fully conform to the guidelines issued by BSEC regarding the reporting and compliance of corporate governance requirement while HPCBs are fully fulfilling this requirement for the improvement of corporate governance. So our eighth hypothesis is also accepted that HPCBs are complying more than the SCBs in respect of RCC.

Since it is found that in respect to all core variables the compliance rate of SCBs is weaker than HPCBs, we explored the compliance status of SCBs and HPCBs in respect to some individual variables of core variables (BD and $\mathrm{AC}$ ) to observe if those carry more significance for financial performance. It is seen from the Cross tabulation (Appendix: Table 3) that in case of internal control $20 \%$ of SCBs are not maintaining the sound internal control system compliance while $100 \%$ of HPCBs are following the internal control compliance system. It reflects that SCBs in Bangladesh lack in internal control system that may have aggravated its lower performance compared to HPCBs. It is also found from table (Appendix: Table 4) that one SCBs is not concerned about its risk where as all HPCBs comply with risk related guidelines which also may be attributed to the poor performance of SCBs compared to HPCBs.

The Cross tabulation in the table (Appendix: Table 5) shows that 20\% of SCBs are not maintaining the proper accounts compliance whereas 100\% of HPCBs are following the proper books of accounts. So it is obvious that SCBs has lacking in respect of maintaining proper books of accounts that may speed up lower performance SCBs comparing the HPCBs.

Our analysis also shows (Appendix table: 6) that SCBs have audit committee of which the members are not financially literate. $40 \%$ members lack required qualification where as $100 \%$ member of Audit committee are financially literate in HPCBs. Again, the result of cross tabulation (Appendix: Table 7) shows that though SCBs have audit committee the member of the audit committee are not so much responsible to director. $40 \% \mathrm{AC}$ is showing indifference about reporting to director while $100 \% \mathrm{AC}$ are aware about reporting to board. It can also contribute to poor performance of SCBs. 
Compliance with Corporate Governance Guidelines: A Comparative Study of High-performing Private Commercial Banks and State-owned Commercial Banks in Bangladesh

Table11. SCBs Sample Company Compliance Attitudes

\begin{tabular}{|c|c|c|c|c|l|}
\hline $\begin{array}{c}\text { Compliance } \\
\text { key }\end{array}$ & Mean & SD & $\begin{array}{c}\text { CV (In } \\
\text { percentage) }\end{array}$ & Rank & \multicolumn{1}{|c|}{ Comments } \\
\hline CHC & 1.8 & .4472136 & $24.85 \%$ & $\mathbf{2}$ & Consistency comparatively more in this section \\
\hline BD & 35.4 & 7.056912 & $19.93 \%$ & $\mathbf{1}$ & Consistency comparatively more in this section \\
\hline AC & 19.4 & 5.128353 & $26.43 \%$ & $\mathbf{3}$ & Consistency comparatively more in this section \\
\hline ESA & 7.4 & 2.607681 & $35.29 \%$ & $\mathbf{5}$ & Consistency less in this section \\
\hline SC & 3.8 & 1.30384 & $34.31 \%$ & $\mathbf{4}$ & Consistency less in this section \\
\hline DCEO & 3.2 & 1.30384 & $40.75 \%$ & $\mathbf{6}$ & Consistency far less in this section \\
\hline RCC & 1.6 & .8944272 & $55 \%$ & $\mathbf{7}$ & Consistency far less in this section \\
\hline
\end{tabular}

Table12. HPCBs s Sample company compliance attitudes

\begin{tabular}{|c|c|c|c|c|l|}
\hline Compliance key & Mean & SD & CV (In percentage) & Rank & \multicolumn{1}{c|}{ Comments } \\
\hline CHC & 2 & 0 & 0 & $\mathbf{1}$ & Consistency more in this section \\
\hline BD & 41.2 & 1.30384 & $3.16 \%$ & $\mathbf{2}$ & Consistency more in this section \\
\hline AC & 23 & 1.414214 & $6.15 \%$ & $\mathbf{3}$ & Consistency less in this section \\
\hline ESA & 8.6 & .5477226 & $6.37 \%$ & $\mathbf{4}$ & Consistency less in this section \\
\hline SC & 4.8 & .4472136 & $9.31 \%$ & $\mathbf{5}$ & Consistency less in this section \\
\hline DCEO & 3.8 & .4472136 & $11.77 \%$ & $\mathbf{6}$ & Consistency far less in this section \\
\hline RCC & 2 & 0 & 0 & $\mathbf{1}$ & Consistency more in this section \\
\hline
\end{tabular}

From the above two tables (Table 11 and Table 12) it is seen that CHC and RCC has 100\% consistency in HPCBs because their co-efficient of variation is 0 while SCBs shows highest level of inconsistency in respect to RCC that is 55\%. Highest CV denotes less consistency in compliance guidelines and lowest $\mathrm{CV}$ explains more consistency in compliance guidelines. It is also seen that in respect of all variables, SCBs has lower consistency or more variation than HPCBs. In case of SC, ESA and DCEO SCBs s has low consistency their CV is $34.31 \%, 35.29 \%$ and $40.75 \%$ respectively. On the other hand, RCC of SCBs has the lowest level of consistency as its CV is 55\%. From the coefficient of variance analysis, the low level or more varied compliance of SCBs than HPCBs is also disclosed.

\section{MAJOR FINDINGS AND RECOMMENDATION}

This study shows that, in Bangladesh, SCBs' overall compliance with corporate governance guidelines issued by BSEC is not satisfactory though two banks have shown positive compliance status. In contrast, the overall compliance of HPCBs is satisfactory and is more than $90 \%$, which reflects the corporate governance compliance of high performance banks are also high compared to SCBs. Descriptive statistics of seven main variables generated by STATA also shows compliance of SCBs is weaker than HPCBs in respect to BD, CHC, AC, ESA, SC, DCEFO and RCO. For deep investigation, by using SPSS we have also analyzed some cross tabulation of sub variables in case of $\mathrm{BD}$ and $\mathrm{AC}$ which shows corporate governance compliance of SCBs is also not satisfactory compared to HPCBs in terms of some sub variables. From our study, we can conclude that low rate of corporate governance compliance is one cause of bad performance of state owned commercial banks in Bangladesh in recent year. In this background the study is proposing following recommendations for the improvement of corporate governance in SCBs in Bangladesh:

$>$ First of all, as SCBs do not follow majority of the guidelines by BSEC, they should give more attention on all issues of BSEC guidelines. More specifically, they should emphasize on independent director, casual vacancy requirement, review of fraudulent issue, reporting to shareholders and commission about any fraud, and conflict of interest.

SCBs should strengthen internal controls system and audit should be carried out by independent and external auditor. HPCBs can be exemplary for them in this regard.

SCBs should start institutional reforms for transparency and accountability that may lead to better corporate governance and offer high financial performance like PCBs.

> It is familiar phenomenon in Bangladesh that activities of SCBs are mostly dominated and imposed by political people. This study also reveals that most of the directors are appointed by the government. It may be one of the reasons for which qualification of management was found poor. 
So, the government should avoid such type of practices which itself expose banks to noncompliance of corporate governance.

$>$ The regulatory role should be separated from the state's ownership and allow more flexibility in capital structures while making sure that SCBs face competitive access to finance.

$>$ Political interference should be minimized in day-to-day management and should introduce transparent nomination process for boards, based on competence and skills. HPCBs seem to have relative low interference is such issue and show better performance.

SCBs should produce aggregate performance report and become self reliant avoiding financial assistance from the state.

SCBs should invest more in ICT to ensure and improve their corporate governance practice. ICT can give access to banks' compliance disclosure to all its stakeholders including customers and regulatory authority and promotes transparency.

\section{Conclusion}

While the application of sound corporate governance practices in the state owned banks (SCBs) could have a significant effect on the economy, in this study, we found the practice is almost absent or at least very weak compared to high-performing private commercial banks (HPCBs). Though none of the banks were found fully compliant with corporate governance guidelines by BSEC, the HPCBs showed very high compliance. The acceptance and better compliance of corporate governance principles by SCBs in Bangladesh will be a significant step towards making good performance of the banks. We identified specific issues where the SCBs should focus on and offered some suggestions based on findings to improve compliance with corporate governance guidelines, hence to ensure better financial performance. It will also create safeguard against corruption and mismanagement, promote transparency in corporate life and attract foreign investment. Future studies can provide a comparative analysis by adopting both BSEC and BB guidelines and its impact on banks' performance.

\section{REFERENCES}

Ahmed, S. (2015). Banking Sector: Regulations, Compliance and Good Governance.24th Anniversary of The Daily Star (Part 1), 23rd march, 2015.

Agoraki, M. K. A., Delis, M. D. and Staikouras, P. K. (2010). The effect of board size and composition on bank efficiency, International Journal of Banking, Accounting and Finance, 2 (4), pp. 357-86.

AL-Shiab, M. (2003). Financial consequences of I AS adoption: the case of Jordan. PhD. Thesis, University of Newcastle, Upon -Tyne, UK.

Ararat, M. and Ugar, M. (2003). Corporate Governance in Turkey: An Overview and Some policy Recommendation, 3(1).

Bangladesh Bank annual report (2015-2016). Retrieved on April 6, 2013, retrieved from https://www. bb.org.bd/pub/annual/anreport/ar1516/chap5.pdf

Berlin, M., Saunders, A. and Udell, G. (1991), Deposit insurance reform: what are the issues and what needs to be fixed?, Journal of Banking and Finance, 2(15), pp. 735-752.

Cengiz, H. ( 2016). Corporate Governance and Firm Profitability: Evidence from Turkey, International Journal of Trade, Economics and Finance, 7(6)

Chaudhury, S. K., Das, S. K. and Mishra, D. P. (2011). Corporate governance practices in selected Indian financial institutions, European Journal of Business and Economics, 5, pp. 39-48.

Choudhury, M. A. and Hoque, M. Z. (2006). Corporate governance in Islamic perspective., Corporate Governance, 6 (2), pp. 116-128.

Davies, M. and Schlitzer, B. (2008).The impracticability of an international "one size fits all" corporate governance code of best practice., Managerial Auditing Journal, 23(6), pp.532-554.

Ekwueme, C. M. and Akhalumeh, P. (2016). A Effectiveness of corporate governance practices in Nigeria: A comparative analysis of selected firms, Arabian Journal of Business and Management Review (Oman Chapter), 5(9), pp.19-33.

Fernando, A. C. (2006). Corporate governance: principles, policies and practices, S. P. Printers, Delhi. 
Filatotchev, I., Wright, M., Uhlenbruck, K., Tihanyi, L. and Hoskisson, R. E. (2003).

Governance, organizational capabilities, and restructuring in transition economies, Journal of World Business, 4(38), pp.331-347.

Franks, J. , Mayer, C. and Rossi, S. (2009). Ownership: evolution and regulation, Review of Financial Studies, 2(12), pp. 139-143.

Gospel, H. and Pendleton, A. (2005). Corporate governance and labor management: An international comparison. Oxford university press Inc., New York.

Haque, M. Z. (2016). Prospective Area of ICT use to improve the performance of Corporate Governance in Bangladesh, The Cost \& Management, Volume 44 , No.2, March-April, pp.4-18.

Haque, M. Z. and Mia, M. A. H. (2014). Corporate Governance Notification Compliance (CGNC) of Islamic Shariah Based Banks (ISBBs) and Conventional Banks Having

Islamic Windows (CBHIWs)- A case of Bangladesh., Bangladesh Journal of MIS, Volume 7, No.1, December, pp.77-94.

Haque, M. Z. (2014). Corporate Governance Compliance of Islamic Shariah Based Banks(ISBBs) in Bangladesh., The Cost \& Management, Volume XLII,No.3, May-June, pp.4-18.

Hasan, M. S., Hossain,S. Z. and Swieringa, R. J. (2013). Corporate governance and financial disclosure: Bangladesh perspective, Research Journal of Finance and Accounting, 4(1) pp.109120.

Hasan, M. S. and Hossain, S. Z. (2012). Measurement and analysis of disclosure level: Bangladesh perspective, Italic and Maximal Capitalization for Journal Title, 10(2), pp.15-19.

Islam, M. A., Siddiqui, M. H., Hossain, K. F. and Karim, L. (2014). Performance Evaluation of the Banking Sector in Bangladesh: A Comparative Analysis, Business and Economic Research, 4(1), pp.70-107.

Johnson, S., Boone, P., Breach, A. and Friedman, E. (2000). Corporate governance in the Asian financial crisis, Journal of Financial Economics, 58(2000), pp.141- 186.

John, K. and Senbet, L. W. (1998). Corporate governance and board effectiveness, Journal of Banking and Finance, 22.( 4), pp. 371-403.

John, R. and Afshad, J. (2008). Do corporate governance attributes affect adverse selection costs? Evidence from seasoned equity offerings, Review of Quantitative Finance and Accounting, 3(30), pp. 281-296.

Kimberly, C. G., Kim, I., Kim, Y. H. and Kim,Y.S. (2011). Corporate governance and diversification, Review of Quantitative Finance and Accounting, 2(11), pp. 201-226.

Kim, P.k., Rasiah, D.and Tasnim, R.B. (2012). A review of corporate governance ownership structure of domestic-owned banks in term of government connected ownership of commercial banks in Malaysia, Journal of organizational management studies.

Kin, W. and Baruch, L.(2008). Executive pay dispersion, corporate governance and firm performance, Review of Quantitative Finance and Accounting, 30, pp. 315-338.

Lawrence, D. and Marcus, L. (2009). Corporate governance and firm operating performance, Review of Quantitative Finance and Accounting, 2(32), pp. 129-144.

Lemo, T. (2004). Corporate governance issues. In: NSE Biannual Conference. Malaysia, Journal of organizational management studies, (2012), PP. 18.

Leung, S. and Horwitz, B. (2009). Corporate governance and firm value during a financial crisis, Review of Quantitative Finance and Accounting, 4(34), pp. 459-481.

Mahmud, H., Lim, C.Y and Tan, P. M. (2010). Corporate governance, legal environment, and auditor choice in emerging markets, Review of pacific basin financial markets and policies, 1(13), pp. 91-126.

Mamun, M. Z. and Khan, R. H. (2014). Customers' Satisfaction of Islamic Banking and Conventional Banking in Bangladesh: A Comparative Study, Journal of Business Studies, Vol (XXXV), No. 1, pp. 85-103.

Marsh, T. and Pfleiderer, P. C. (2010). The 2008-2009 Financial Crisis: Risk Model Transparency and Incentives. Rock Center for Corporate Governance at Stanford University. Working Paper no. 72. 
Markus, S., Thomas, F. M. and Patrick, V. (2012). Financial crisis and corporate governance in the financial sector: Regulatory changes and financial assistance in Germany and Europe,

International Journal of Disclosure and Governance, suppl. Special Issue Section: Financial Crises and Regulatory, 9(4), pp. 331-347.

Mishra, C.S., Randoy,T. and Jensen, J. I. (2001). The effect of founding family influence on firm value and corporate governance, Journal of International Financial Management and Accounting, 12(3), pp.235-259.

Monks, R. A. G. and Minow, N. (1996). Watching the watchers: Corporate Governance for the 21st Century, Blackwell Publisher, Cambridge.

Mosharrafa, R. A. (2015). Relative consequences due to absence of corporate governance in nationalized and private commercial banks in Bangladesh, Journal of Economics and International Finance; 7(2) pp. 42-50.

Moshirian, F. and Wu, Q. (2012). Banking industry volatility and economic growth. Research in International Business and Finance, 26, pp.428.

Okeahalam, C. C. (2004). Corporate Governance and Disclosure in Africa: Issues and Challenges, Journal of Financial Regulation and Compliance, 12(4), pp.359-370.

Park, J. (2012). Corruption, soundness of the banking sector, and economic growth: a cross-country study., Journal of International Money and Finance. 31(5), pp. 907- 929.

Paul, D. and Dan, D. (2013). Is Religion an Influential Factor in the Managerial Decision Taken at the Level of Corporate Governance Structures?', International Conference on Management, Leadership \& Governance, 2013, pp.75-82.

Rahman, M. M. (2016). Financial Performance Analysis of Scheduled Commercial Banks in Bangladesh, Universal Journal of Accounting and Finance, 4(5), pp.166-184.

Rahman, M. M., Bashir, M. M. A., Choudhury, T. T. and Rabby, S. M.(2014). Disclosure of

Corporate Governance in Banking Sector of Bangladesh, European Journal of Business and Management, 6(6), pp.17-37.

Rehman, K. U. and Din, M. S. (2013). Impact of Corporate Governance on Performance of Firms, A Case Study of Cement Industry in Pakistan, Journal of Business and Management Sciences, PP. 44-46.

Rezaee, R., Olibe K.O. and Minmier, G. (2003). Improving corporate governance: The role of audit committees, Managerial Auditing Journal, 6/7(18) pp. 530-537.

Ross, A. and Crossan, K.(2012). A review of the influence of corporate governance on the banking crises in the United Kingdom and Germany., Corporate Governance; Emerald publishing, 12(2), pp. 215-225.

Sa'eed, M. A. ( 2013). Compliance with the principles of corporate governance: Different perspectives from Jordan, Accounting and Management Information Systems; 12(4) pp. 553-577.

Serwa, D. (2010). Larger crises cost more: impact of banking sector instability on output growth, Journal of International Money and Finance. 29, pp. 1463-1481.

Siddique, J. S. (2010). Development of corporate governance regulations: The case of an emerging economy, Journal of Business Ethics, 9(1), pp. 253-274.

Thanh, T.T., Hong, S. N. and Bao, K. P. (2014). Testing the Relationship between Corporate Governance and Bank Performance - An Empirical Study on Vietnamese Banks, Asian Social Science, 10(9), pp. 213-226.

Yeoh, J. (2005). Compliance with mandatory disclosure requirements by New Zealand Listed Companies, Advances in International Accounting, 18, pp. 245-262.

Wen, C. L. and Shao, C. (2012). Corporate governance and the stock market reaction to new product announcements, Review of Quantitative Finance and Accounting, 2(39), pp. 273-291. 
Compliance with Corporate Governance Guidelines: A Comparative Study of High-performing Private Commercial Banks and State-owned Commercial Banks in Bangladesh

\section{APPENDIX}

Table1. Selected SCBs for this research

\begin{tabular}{|c|c|c|}
\hline Serial No. & Banks Name & Company Key \\
\hline 1. & Sonali Bank Limited & SBL \\
\hline 2. & Janata Bank Limited & JBL \\
\hline 3. & Bangladesh Development Bank Limited \\
\hline 4. & Agrani Bank Limited & ABL \\
\hline 5. & Basic Bank Limited & BBL \\
\hline
\end{tabular}

Table2. Selected HPCBs for this research

\begin{tabular}{|c|c|c|}
\hline Serial No. & Banks Name & Company Key \\
\hline 1. & Dutch Bangla Bank Limited & DBBL \\
\hline 2. & Pubali Bank Limited & BBL \\
\hline 3. & Brac Bank Limited & CBL \\
\hline 4. & City Bank Limited & IBBL \\
\hline 5. & Islami Bank Bangladesh Limited \\
\hline
\end{tabular}

Table3. Soundness of Internal control system

\begin{tabular}{|l|l|l|l|l|l|l|l|}
\hline \multicolumn{2}{|l|}{ Soundness of Internal control system (SCBs) } & Total & \multicolumn{4}{l|}{ Soundness of Internal control system (HPCBs) } & Total \\
\hline & Not complied & Complied & & & Not complied & Complied & \\
\hline Board Size & 1 & 4 & 5 & Board Size & 0 & 5 & 5 \\
\hline Total & 1 & 4 & 5 & Total & 0 & 5 & 5 \\
\hline
\end{tabular}

Table4. Concerned about risk compliance

\begin{tabular}{|l|l|l|l|l|l|l|l|}
\hline Proper Books of accounts (SCBs) & Total & Proper Books of Accounts (HPCBs) & Total \\
\hline & Not complied & Complied & & & Not complied & Complied & \\
\hline Board Size & 1 & 4 & 5 & Board Size & 0 & 5 & 5 \\
\hline Total & 1 & 4 & 5 & Total & 0 & 5 & 5 \\
\hline
\end{tabular}

Table5. Maintaining Proper Books of Accounts Requirement

\begin{tabular}{|l|l|l|l|l|l|l|l|}
\hline Proper Books of accounts (SCBs) & Total & \multicolumn{4}{l|}{ Proper Books of Accounts (HPCBs) } & Total \\
\hline & Not complied & Complied & & & Not complied & Complied & \\
\hline Board Size & 1 & 4 & 5 & Board Size & 0 & 5 & 5 \\
\hline Total & 1 & 4 & 5 & Total & 0 & 5 & 5 \\
\hline
\end{tabular}

Table6. Compliance of Audit committee Members' qualification requirement

\begin{tabular}{|l|l|l|l|l|l|l|l|}
\hline \multicolumn{2}{|c|}{ All members are financially literate (SCBs) } & Total & \multicolumn{3}{|c|}{ All members are financially literate (HPCBs) } & Total \\
\hline & Not complied & Complied & & & Not complied & Complied & \\
\hline Audit committee & 2 & 3 & 5 & Audit committee & 0 & 5 & 5 \\
\hline Total & 2 & 3 & 5 & Total & 0 & 5 & 5 \\
\hline
\end{tabular}

Table7. Compliance of Audit committee responsible to board

\begin{tabular}{|l|l|l|l|l|l|l|l|}
\hline $\begin{array}{l}\text { Audit committee responsible to director } \\
\text { (SCBs) }\end{array}$ & Total & \multicolumn{2}{l|}{$\begin{array}{l}\text { Audit committee responsible to director } \\
\text { (HPCBs) }\end{array}$} & Total \\
\hline & Not complied & Complied & & & Not complied & Complied & \\
\hline Audit committee & 2 & 3 & 5 & Audit committee & 0 & 5 & 5 \\
\hline Total & 2 & 3 & 5 & Total & 0 & 5 & 5 \\
\hline
\end{tabular}

Table8. Summaries of Notifications on Corporate Governance Issued by BSEC

\begin{tabular}{|l|l|}
\hline Clause & \multicolumn{1}{|c|}{ Description of clause } \\
\hline $\mathbf{1 . 0}$ & Board of Directors \\
\hline $\mathbf{1 . 1}$ & Board's Size should not be less than 5 (five) and more than 20 (twenty) \\
\hline $\mathbf{1 . 2}$ & $\begin{array}{l}\text { Independent Directors should be one out of fifth boards of directors } \\
\text { Independent directors should not hold any share in the company or should hold less than one } \\
\text { percent (1\%) shares of the total paid-up shares of the company. He/she will not be a sponsor of the } \\
\text { company and connected with the company's any sponsor or director or shareholder in a }\end{array}$ \\
\hline
\end{tabular}




\begin{tabular}{|c|c|}
\hline & $\begin{array}{l}\text { relationship. He/she will not have any other relationship, whether pecuniary or otherwise, with the } \\
\text { company or its subsidiary/associated companies. He/she will not be a member, director or officer of } \\
\text { any stock exchange and not be a shareholder, director or officer of any member of stock exchange } \\
\text { or an intermediary of the capital market. He/she will not be a partner or an executive or was not a } \\
\text { partner or an executive during the preceding } 3 \text { (three) years of the concerned company's statutory } \\
\text { audit firm. He/she will not be an independent director in more than } 3 \text { (three) listed companies and } \\
\text { will not be convicted by a court of competent jurisdiction and involving moral turpitude. He/she } \\
\text { will be an independent director for concerned company for a period of } 3 \text { (three) years, which may } \\
\text { be extended for } 1 \text { (one) term only }\end{array}$ \\
\hline 1.3 & $\begin{array}{l}\text { Independent Director (ID) shall be a knowledgeable individual with integrity and should be } \\
\text { Business Leader/Corporate Leader/Bureaucrat/University Teacher with Economics or Business } \\
\text { Studies or Law background/Professionals like Chartered Accountants, Cost \& Management } \\
\text { Accountants, Chartered Secretaries and must have at least } 12 \text { (twelve) years of corporate } \\
\text { management/professional experiences. }\end{array}$ \\
\hline 1.4 & $\begin{array}{l}\text { The chairman of the board and Chief Executive Officer (CEO) must be different person their } \\
\text { respective role and responsibility would be clearly defined by the board of directors. }\end{array}$ \\
\hline 1.5 & $\begin{array}{l}\text { The directors of the companies should disclose the following information to shareholders: } \\
\text { Industry outlook and possible future developments in the industry, Segment-wise or product-wise } \\
\text { performance, Risks and concerns, Discussion on Cost of Goods sold, Gross Profit Margin and Net } \\
\text { Profit Margin and continuity of any Extra-Ordinary gain or loss, Basis for related party } \\
\text { transactions, Utilization of proceeds from public issues, rights issues and/or through any others } \\
\text { instruments, Fairness of state of affairs/ Financial Statements, Maintenance proper books of } \\
\text { accounts, Consistent application of accounting policies in preparation of financial, Compliance } \\
\text { with International Accounting Standard, Soundness and efficiency of internal control system, } \\
\text { Ability of Company to continue as a going concern, Significant deviations from last year in } \\
\text { operating results, Presentation of key operating and financial data for last three years, Declare } \\
\text { dividend, Number of board meetings held during the year and attendance by each director, Sharing } \\
\text { Pattern, internal control system, significant deviation of last operating results, key operating and } \\
\text { financial data of last } 5 \text { years, status of issuer company regarding declaration of dividend } \\
\text { number of board meeting, Information about subsidiary or associated company }\end{array}$ \\
\hline 2.0 & $\begin{array}{l}\text { Chief Financial Officer(CFO), Head of Internal Audit and Company Secretary } \\
\text { CFO, Head of Internal Audit and Company Secretary will be appointed by board and must attend } \\
\text { the board meeting }\end{array}$ \\
\hline 3.0 & $\begin{array}{l}\text { Audit Committee of a company should act as a subcommittee of the Board of Directors. Audit } \\
\text { committee should be composed of at least } 3 \text { members and out of them } 1 \text { should be independent } \\
\text { directors. Independent directors will be the chairman of audit committee and all members must be } \\
\text { financially literate. Vacancy of audit committee must be filled within } 1 \text { month. Audit committee } \\
\text { will oversee the financial reporting process, monitor choice of accounting policies and principles } \\
\text { and Internal Control, Risk management process ,oversee hiring and performance of external } \\
\text { auditors ,review along with the management, the annual financial statements, the quarterly and half } \\
\text { yearly financial before submission to board for approval, Review the adequacy of internal audit } \\
\text { function and related party transactions submitted by the management, Review Management Letters/ } \\
\text { Letter of Internal Control weakness issued by statutory auditors, Disclose information about the } \\
\text { uses/applications of funds raised by IPO or RPO. }\end{array}$ \\
\hline 4.0 & $\begin{array}{l}\text { External /Statutory Auditors should not engage in appraisal or valuation services or fairness } \\
\text { opinions, } \\
\text { Financial information systems design and implementation, book-keeping or other services related } \\
\text { to the accounting records or financial statements, broker-dealer services, actuarial Services, Internal } \\
\text { audit services, any other services that the Audit Committee determines and no partner or employees } \\
\text { of the external audit firms shall possess any share of the company they audit at least during the } \\
\text { tenure of their audit assignment }\end{array}$ \\
\hline 5.0 & $\begin{array}{l}\text { Board of director of subsidiary will be formed as per provision applicable to holding company. } \\
\text { There should have at least one independent director. Minutes of board meetings of subsidiary } \\
\text { should be placed to board meeting of holding and audit committee of holding company will review } \\
\text { the financial statement of subsidiary company }\end{array}$ \\
\hline 6.0 & $\begin{array}{l}\text { The CEO and CFO shall certify to the Board that they have reviewed financial statements for the } \\
\text { year and to the best of their knowledge and belief there is no materially untrue statement and the } \\
\text { statement reflect true and fair view of the company. They should certify that all existing accounting } \\
\text { standard and laws are applied and there is no fraudulent and illegal information. }\end{array}$ \\
\hline
\end{tabular}




\begin{tabular}{|l|l|}
\hline \hline 7.0 & $\begin{array}{l}\text { The company shall obtain a certificate from a practicing Professional Accountant/Secretary } \\
\text { (Chartered Accountant/ Cost and Management Accountant/Chartered Secretary) regarding } \\
\text { compliance of conditions of Corporate Governance Guidelines of the Commission and shall send } \\
\text { the same to the shareholders along with the Annual Report on a yearly basis. The directors of the } \\
\text { company shall state, in accordance with the annexure attached, in the directors' report whether the } \\
\text { company has complied with these conditions. }\end{array}$ \\
\hline
\end{tabular}

\section{AUTHORS' BIOGRAPHY}

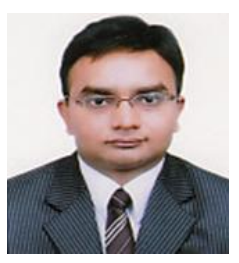

Rezwanul Huque Khan, is a doctoral researcher in Information Systems Management at Warwick Business School, University of Warwick, UK. He is an Assistant Professor of Institute of Business Administration, University of Dhaka. Mr. Khan is a Commonwealth Scholar and has been involved in teaching at different universities in Bangladesh for more than twelve years. His research investigates into diverse theoretical and practical issues. Among others, his primary research interest focuses on e-commerce, ICT4D and digital service innovation, and he has several publications in leading national and international journals in the field of business studies.

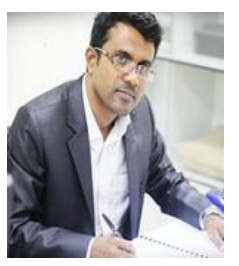

Md Ziaul Haque, is a $\mathrm{PhD}$ student at University of International Business and Economics (UIBE) in Beijing, China. He has around seven years of teaching experience as a full time and visiting faculty member at different universities in Bangladesh. His publications appeared in different national and International Journals and also in International conference proceedings. His research interests include Corporate Governance, Management Information Systems, Information and Communication technology, Self service technology, Social Networking and AIS. 